\title{
Development of E-ATCM (Accounting Trading Company Module) as an Interactive Digital Learning Media During the Covid-19 Pandemic
}

\author{
Betanika Nila Nirbita ${ }^{*}$, Sri Hardianti Sartika \\ Economic Education, Faculty of Teaching Traning and Education, Siliwangi University \\ *Corresponding Author. Email: betanika@unsil.ac.id
}

\begin{abstract}
This study aims to analyze the feasibility of implementing E-ATCM (Accounting Trading Company Module) in the Basic Financial Accounting Course for Economic Education during the Covid-19 Pandemic. The research method uses Research and Development, which is limited to research procedures to product feasibility tests. The instrument used in the E-ATCM feasibility test is in the form of a questionnaire, which consists of media validation tests by experts, and field tests by students. The data analysis technique was carried out with qualitative descriptive data analysis to determine improvement decisions in the development of E-ATCM. From this research, it shows that the E-ATCM media is suitable for use as a learning media for Basic Financial Accounting during the Covid-19 Pandemic. The value of the feasibility of learning media based on material experts is $94.64 \%$, media experts $93 \%$, linguists $90.65 \%$, and practical experts $94.85 \%$. The percentage of material, media, language, and practical experts is in very decent criteria. The next stage is a limited trial with a value of $85.94 \%$ on a very feasible criterion and a broad trial with a value of $90.98 \%$ on a very feasible criterion. So it can be concluded that the E-ATCM media is suitable for learning in Basic Financial Accounting courses.
\end{abstract}

\section{Article History}

Received: 23-09-2021

Revised: 27-10-2021

Accepted: 11-11-2021

Published: 11-12-2021

\section{Key Words:}

Learning Media, E-

Module,

Accounting

Education,

Covid-19.

How to Cite: Nirbita, B., \& Sartika, S. (2021). Development of E-ATCM (Accounting Trading Company Module) as an Interactive Digital Learning Media During the Covid-19 Pandemic. Jurnal Kependidikan: Jurnal Hasil Penelitian dan Kajian Kepustakaan di Bidang Pendidikan, Pengajaran dan Pembelajaran, 7(4), 924-932. doi:https://doi.org/10.33394/jk.v7i4.4317

\section{Introduction}

The Covid-19 pandemic has changed all aspects of human life. This pandemic forced many Schools and Higher Education Institutions to close temporarily, various schools and Higher Education Institutions have stopped face-to-face teaching. Kandri (2020) states that this change affects education by almost $90 \%$, this occurs at various levels of education including basic education, secondary education and higher education. As a result, educational institutions cannot carry out physical learning activities, such as going to school or university. Dhawan (2020) adds that there is no certainty that there will be a return to normal to face-toface teaching and learning in the near future, so various educational institutions must struggle to find options in dealing with this challenging situation. So that online learning is one of the urgent scenarios for educational institutions. The spread of Covid-19 which has resulted in the closure of educational institutions around the world, thus testing the readiness of universities to face a crisis that requires technological assistance so that distance learning can run effectively. In line with Daniel (2020) the Covid-19 pandemic is a big challenge for the Education system which in increasing the capacity of teaching and learning remotely, schools and universities must take advantage of asynchronous learning, and the most effective media is in digital format..

Higher Education has a standard learning process that is regularly reviewed and adapted to the development of science and technology (Permendikbud 3 Tahun 2020, n.d.). 
During this pandemic, higher education institutions are required to provide various learning media that support distance learning. Sun, et al.(2020) states that online learning is a real form of digital technology development which is not limited to the era of the industrial revolution 4.0. Cojocariu (2014) asserts that many terms that refer to distance learning such as online learning, web-based learning, or computer-mediated learning or other terms, are defined as learning that provides the possibility for students to learn anywhere and anytime and knows no boundaries. space and time. Distance learning is said to be a teaching and learning process that makes learning centered on students and more innovative and even flexible. According to Sartika (2021) learning materials obtained by utilizing the internet and software-based multimedia are one of the characteristics of distance learning.

Distance learning is designed so that students get a synchronous and asynchronous learning experience by using a touch of technology such as laptops and cellphones, whether with internet access or not, so that students are able to study independently but they remain connected to the social learning environment, namely lecturers and other students (Singh \& Thurman, 2019) Distance learning has caused many changes in education, because a new paradigm of modern education has emerged and has changed the previous concept of learning (Hassanzadeh et al., 2012). Online learning is part of distance education, the approach used in distance learning is to utilize coaching and facilitated learning by building knowledge with software-based multimedia learning. This is in line with Alias and Siraj (2012), that the use of technology in education is one way to understand concepts that are difficult to learn and change them from abstract to concrete to make them easier to understand.

The technology used in learning enables educators to encourage interaction and collaboration among students in a distance learning environment. Interaction has been considered as one of the most important factors in student satisfaction in distance learning, student satisfaction is considered as one of the five pillars of online education quality (Bolliger et al., 2010). ICT learning media will encourage students to think critically (Nirbita et al., 2018). Distance learning implies the need to use a new learning structure that fits the characteristics of distance learning. Several software-based multimedia have been used in the development of instructional materials to support distance learning.

Technology is an inseparable part of modern life. In the field of education, technology is very much needed in distance learning activities during this pandemic. So that softwarebased learning multimedia in the form of digital teaching materials is one of the main needs in the field of education in the 4.0 era. Digital teaching materials continue to be innovated in various forms such as E-modules in learning. According to Chaeruman (2014) what is meant by E-module or electronic-based module is a software-based learning module that can be accessed and studied anytime and anywhere. Nirbita, et. al. (2017) states students will find it easier to understand when using media as teaching materials, especially when using flexible media.

Retzlaff, et al. (Retzlaff et al., 2020) stated that E-modules have several potential advantages over other learning media, E-modules tend to save costs because after making Emodules they can be used repeatedly. Research conducted by Hollingsworth \& Lim (2015) shows that teaching in Higher Education using E-modules is proven to be effective in increasing students' knowledge and competence, as well as meeting learning objectives. In addition, students are able to learn instructions through E-modules more effectively than traditional learning methods. Ullah et al. (2018) argue that the key components of learning and teaching should be taken into account when designing a module. These components include curriculum, learning outcomes. teaching and learning strategies (methods) and assessment approaches in evaluating learning outcomes. 
Bloom's taxonomy provides useful direction in understanding the level of learning to be achieved in a module and the knowledge-related skills included in the learning objectives of the accounting module (Ullah et al., 2018). E-modules can be easily integrated into learning to support better student learning outcomes (Kowitlawakul et al., 2017). The learning module designed must be able to provide self-instructional, self-contained, adaptive, and user friendly (Logan et al., 2021). E-modules allow students to repeat parts they do not understand, providing opportunities for students to study independently so as to improve their learning outcomes. The use of E-modules at the higher education level can be used as an addition to distance learning by providing flexible and independent learning media (Abuatiq et al., 2017; McDonald et al., 2018).

In distance learning which has been going on for one year, educators at the university level use several learning platforms such as Google Classroom, Google Meet, Zoom, WhatsApp, and others. But in reality the platform has limitations for students who are in a signal difficult zone. They have difficulty understanding learning because the online learning process is not going well, so they need learning media that can be studied on their own and can be repeated if students have difficulty learning distance. Seeing this phenomenon, the use of E-modules is very much needed by students, especially in distance learning during this Pandemic. Based on the results of interviews and observations, it was found that students of the Department of Economics Education FKIP Siliwangi University needed E-modules to support Basic Financial Accounting learning, in addition to E-Modules that could be accessed without using quotas so that they could be used more flexibly, wherever and whenever.

Basic Financial Accounting course is one of the courses contained in the Curriculum of the Department of Economics Education FKIP-UNSIL. This course discusses the concept of recording and disclosing cash flows and operations, as well as dividing all business transactions into credits and debits. One of the sub-materials in this course is trading company accounting which discusses the process of preparing trading company financial reports for a certain period. The cycle of trading company accounting in general always starts with transactions until the preparation of the company's financial statements, then continues with the balance sheet which is closed with closing journals and reversing journals.

The International Accounting Education Standards Board (IAEB) is a leading body in promoting accounting education worldwide, considering learning outcomes to be "instrumental" in creating a pool of highly professional and competent accountants (IAESB, 2016). The design and preparation of the right learning modules can help in improving technical accounting skills, so it is necessary to conduct a feasibility test on the E-module learning media before being used in the teaching and learning process. E-ATCM is a digitalbased learning media that can be used repeatedly without having to use a quota, as a fulfillment of requests from students in improving learning outcomes and understanding basic financial accounting materials. This study aims to test the feasibility of the E-ATCM learning media for teaching and learning activities in the Basic Financial Accounting Course for Economic Education during the Covid-19 Pandemic.

\section{Research Method}

This research method uses the Research and Development (R\&D) method in the sense of developing teaching material media or E-modules. Gall, et al (2007) said that R\&D research is research used in developing and validating products used in education or teaching and learning processes. R\&D is an effort to develop and produce products in the form of materials, media, tools, or learning strategies used in the teaching and learning process. 
Products developed using the $R \& D$ research method are not intended as a way to test a theory.

In line with Gagne (2010) stated that educational research and development (R\&D) is a process used to develop and validate educational products. In this study, the product developed in the form of an E-module in the Basic Financial Accounting course for Trading Company Accounting material will hereinafter be referred to as E-ATCM. The e-module that will be developed is designed to be easily accessible on a laptop or computer. However, in this study, there is a limitation on the research procedure, only stopping until the product feasibility test is carried out. The product feasibility test will involve several experts, namely material, media, language, and practitioners experts.

The assessment instrument used in the E-ATCM feasibility test uses a questionnaire. The results of the data and information obtained will be analyzed by qualitative descriptive data analysis. Qualitative data analysis is used for feasibility testing carried out by material experts, namely material validation, media, language and practitioners. The measurement of the feasibility test used is from Riduwan (2018) where the percentage obtained is then transformed into qualitative data to determine improvement decisions in product development.

Tabel 1. Product Development Revision Decision Making

\begin{tabular}{ccc}
\hline Interval & Criteria & Explanation \\
\hline $81 \%-100 \%$ & Very feasible & Valid, revision \\
$61 \%-80 \%$ & Feasible & Valid, revision \\
$41 \%-60 \%$ & Decent enough & not valid enough, revision \\
$21 \%-40 \%$ & Not feasible & Not valid, revision \\
$0 \%-20 \%$ & Very not feasible & Not valid, revision \\
\hline
\end{tabular}

Source: Riduwan (2018) developed

\section{Results and Discussion}

E-ATCM (Accounting Trading Company's Module) feasibility testing is carried out through several stages, namely product validation by a team of experts, initial trials, and trials. The feasibility test stages through product validation include the feasibility of materials, media, language, and practitioners involving various experts in their fields. Furthermore, feasibility testing through initial trials and trials involving students of the Department of Economics Education as users of the developed product. The details of the results of the feasibility test that have been carried out are as follows:

\section{1). Product Validation}

Product validation is carried out to assess the feasibility of the product. Validation is done by involving material experts, media experts, linguists, and expert practitioners.

\section{Material Expert Validation}

Table 2. E-ATCM Media Validation Recapitulation by Material Expert

\begin{tabular}{lclllcl}
\hline \multirow{2}{*}{ No } & \multirow{2}{*}{ Aspect } & \multicolumn{5}{c}{ Scoring scale } \\
\cline { 3 - 7 } & & $\mathbf{\Sigma n i}$ & $\mathbf{\Sigma N}$ & $\mathbf{1 0 0 \%}$ & Score & Criteria \\
\hline 1. & Content eligibility & 83 & 88 & 100 & 94,32 & Very Feasible \\
\hline 2. & Serving eligibility & 76 & 80 & 100 & 95 & Very Feasible \\
\hline & Total score & 159 & 168 & 100 & 94,64 & Very Feasible \\
\hline
\end{tabular}

Source: Data processed, 2021

In table 2 it is known that the assessment of the feasibility aspect of the material gets a value of $94.32 \%$ with very feasible criteria. The feasibility aspect of this content includes an assessment of the scope of the material, the accuracy of the material, its updating and 
contextuality and compliance with laws and regulations. While the feasibility aspect of presentation gets a value of $95 \%$ with very decent criteria. Aspects of presentation feasibility include presentation techniques, presentation support and presentation completeness. The total score of the E-ATCM media assessment by material experts is $94.64 \%$ with very decent criteria. The material expert's assessment stated that the E-ATCM was suitable for use in the learning process by making revisions, namely adding examples of various types of transaction evidence in the E-module, and giving the duration for working on the questions.

Media Expert Validation

Table 3. E-ATCM Media Validation Recapitulation by Media Expert

\begin{tabular}{|c|c|c|c|c|c|c|}
\hline \multirow{2}{*}{ No } & \multirow{2}{*}{ Aspect } & \multicolumn{5}{|c|}{ Scoring Scale } \\
\hline & & Eni & $\mathbf{E N}$ & $100 \%$ & Score & Criteria \\
\hline 1. & Display quality & 89 & 96 & 100 & 92,71 & Very Feasible \\
\hline 2. & Technical quality & 97 & 104 & 100 & 93,27 & Very Feasible \\
\hline & Total Score & 186 & 200 & 100 & 93 & Very Feasible \\
\hline
\end{tabular}

Source: Data processed, 2021

Referring to table 3. that the assessment of the quality aspect of the display gets a value of $92.71 \%$ with very decent criteria. The quality aspect of the display includes the background display, the layout design display, the suitability of the size and typeface and the suitability of the placement of images and navigation buttons. The assessment of the technical quality aspect got a score of $93.27 \%$ with very decent criteria. Aspects of quality assessment This technique includes readability, ease of use, the ability to provide feedback and the ability to be used in various learning contexts. The total score of the E-ATCM media assessment by media experts is $93 \%$ with very decent criteria. The results of the assessment by media experts also stated that the E-ATCM media was declared feasible to be used in the learning process by making revisions, namely the existence of instructions for working on essay questions.

\section{Language Expert Validation}

Table 4. E-ATCM Media Validation Recapitulation by Language Expert

\begin{tabular}{llccccc}
\hline \multirow{2}{*}{ No } & \multirow{2}{*}{ Aspect } & \multicolumn{5}{c}{ Scoring scale } \\
\cline { 3 - 7 } & & $\mathbf{\Sigma n i}$ & $\mathbf{\Sigma N}$ & $\mathbf{1 0 0 \%}$ & Score & Criteria \\
\hline 1. & $\begin{array}{l}\text { Language } \\
\text { Component }\end{array}$ & 87 & 96 & 100 & 90,63 & Very Feasible \\
\hline & Total score & 87 & 96 & 100 & 90,63 & Very Feasible \\
\hline
\end{tabular}

Source: Data processed, 2021

Based on table 5.3 it is known that the assessment of the linguistic component gets an assessment of $90.63 \%$ with very decent assessment criteria. The results of the expert assessment stated that E-ATCM was declared feasible to be used in the learning process by making revisions, namely by re-checking grammar, especially spelling writing, which must be based on improved spelling.

\section{Praktitioner Validation}

Table 5. E-ATCM Media Validation Recapitulation by practitioner Expert

\begin{tabular}{llccccc}
\hline \multirow{2}{*}{ No } & \multirow{2}{*}{ Aspect } & \multicolumn{5}{c}{ Scoring Scale } \\
\cline { 3 - 7 } & & $\mathbf{\Sigma n i}$ & $\boldsymbol{\Sigma} \mathbf{N}$ & $\boldsymbol{\%}$ & Score & Criteria \\
\hline 1. & Content Feasibility Aspect & 29 & 32 & 100 & 90,63 & Very Feasible \\
\hline 2. & Presentation feasibility aspect & 42 & 44 & 100 & 95,45 & Very Feasible \\
\hline 3. & Learning approaches & 23 & 24 & 100 & 95,83 & Very Feasible \\
\hline 4. & Media benefits & 35 & 36 & 100 & 97,22 & Very Feasible \\
\hline
\end{tabular}




$\begin{array}{llllll}\text { Total score } & 129 & 136 & 100 & 94,85 & \text { Very Feasible }\end{array}$

Source: Data processed, 2021

Based on table 5.4, it is known that the content feasibility aspect gets a value of $90.63 \%$ with very decent assessment criteria, the presentation feasibility aspect gets a value of $95.45 \%$ with very decent criteria, the learning approach aspect gets a value of $95.83 \%$ with very feasible criteria and usefulness aspects. the media get a score of $97.22 \%$ with very decent criteria. So that the total score of assessment for expert practitioners is $94.85 \%$ with very feasible assessment criteria.

\section{2). Preliminary Field Testing}

Initial field trials or limited trials are trials conducted on a limited scope of at least 612 subjects. The limited trial aims to get criticism and suggestions to produce better E-ATCM media. The limited trial conducted in this study involved 32 students. The limited trial was carried out by distributing student response questionnaires after using the E-ATCM learning media. The results of the recapitulation of student response questionnaires in the limited trial are as follows:

Table 6. Recapitulation of Student Response Questionnaires on Preliminary Field Testing

\begin{tabular}{|c|c|c|c|c|c|c|}
\hline \multirow{2}{*}{ No } & \multirow{2}{*}{ Aspect } & \multicolumn{5}{|c|}{ Scoring Scale } \\
\hline & & Eni & $\Sigma \mathbf{N}$ & $100 \%$ & Score & Criteria \\
\hline 1. & Media Quality & 810 & 896 & 100 & 90,40 & Very Feasible \\
\hline 2. & Media effectiveness & 1320 & 1536 & 100 & 85,94 & Very Feasible \\
\hline To & 1 Score & 2130 & 2432 & 100 & 87,60 & Very Feasible \\
\hline
\end{tabular}

Source: Data processed, 2021

Based on table 6. it is known that the aspect of media quality in the limited trial obtained a score of 90.40 with very decent assessment criteria, while the aspect of media effectiveness in the limited trial obtained a score of 85.94 with very feasible assessment criteria.

\section{3). Main Field Testing}

Main Field trials or broad trials are trials with a wider scope, involving 30-100 subjects. The broad trial aims to determine the user's response to the improved E-ATCM media based on the criticisms and suggestions obtained at the limited trial stage. The alias test in this study was carried out involving 64 students of the Class of 2020. A broad trial was carried out by distributing student response questionnaires after using the E-ATCM learning media. The results of the recapitulation of student response questionnaires in the broad trial are as follows:

Tabel 7. Recapitulation of Student Response Questionnaires on Main Field Testing

\begin{tabular}{llccccc}
\hline \multirow{2}{*}{ No } & \multirow{2}{*}{ Aspect } & \multicolumn{5}{c}{ Scoring Scale } \\
\cline { 3 - 7 } & & $\mathbf{\Sigma n i}$ & $\boldsymbol{\Sigma} \mathbf{N}$ & $\mathbf{1 0 0 \%}$ & Score & Criteria \\
\hline 1. & Media Quality & 1652 & 1792 & 100 & 92,18 & Very Feasible \\
\hline 2. & Media effectiveness & 2795 & 3072 & 100 & 90,98 & Very Feasible \\
\hline \multicolumn{2}{l}{ Total Score } & 4447 & 4864 & 100 & 91,40 & Very Feasible \\
\hline
\end{tabular}

Source: Data processed, 2021

Based on table 7. it is known that the aspect of media quality in the broad trial obtained a value of $92.18 \%$ with very decent assessment criteria, while the aspect of media 
effectiveness in the wide trial obtained a value of $90.98 \%$ with very feasible assessment criteria.

In the development of the E-ATCM learning media, the R\&D research model from the Borg and Gall development model went through ten stages, this is intended so that the designed E-ATCM learning product has a feasibility standard. Based on data and information from the results of the E-ATCM feasibility test that has been carried out, it states that EATCM is an interactive digital learning media that is declared feasible to be used as a learning medium. E-ATCM is a learning media with advantages that can be accessed without using an internet signal, so that it becomes a solution for students who are in difficult signal areas. This feasibility test is in line with research conducted by Hayati, et al (2015) that the development of interactive learning media in the form of a flipbook with the ADDIE research model (Analysis, Design, Development, Implementation, and Evaluation) shows the value of the feasibility test results of $95.78 \%$ with the words Other learning media are suitable for use in teaching and learning activities. The ADDIE development model for educational products was also carried out by Saidah (2015) regarding interactive learning media showing that interactive digital module media was declared feasible in accounting learning. This was also reinforced by other research on interactive learning media in accounting learning, namely from Wulandari, et al. (2017) that interactive learning media in the form of adobe flash with the Brog and Gall development model that has been modified into seven stages, the results of the feasibility test on the media are stated that it is suitable for use in accounting learning.

\section{Conclusion}

The conclusions obtained from the results of the E-ATCM feasibility test include: (1) The product validation test results show that the assessment includes material validation test $94.64 \%$, media validation test $93 \%$, language validation test $90.63 \%$, and practitioner validation test $94.85 \%$. The results of the assessment show that the E-ATCM has criteria that are very suitable to be used in the teaching and learning process in the Basic Financial Accounting course with trade finance accounting material, by making minor revisions in the form of adding examples of various types of transaction evidence, giving duration for working on questions, instructions and instructions for working on essay questions, as well as re-checking grammar, especially spelling writing, must be based on improved spelling. (2) The results of the feasibility test of the initial field trial or limited trial with an assessment of $90.4 \%$ on the aspect of media quality and $85.94 \%$ on the aspect of media effectiveness. The value of the number states that the E-ATCM is declared suitable for use. (3) The results of the E-ATCM feasibility test were carried out by field trials with an assessment of $92.18 \%$ on the media quality aspect and $90.98 \%$ on the media effectiveness aspect. The value of the number states that the E-ATCM is declared feasible to use.

\section{Recommendation}

Distance learning during the Covid-19 pandemic requires universities to focus on using technology more efficiently, namely the use of technology that has minimal procurement and maintenance costs but can facilitate the educational process effectively. E-ATCM learning media is expected to be a solution in distance learning in Basic Financial Accounting courses. However, because this research is limited to the feasibility test of learning media, it is necessary to conduct further research on the level of effectiveness of E-ATCM in the teaching and learning process. The level of effectiveness obtained can later be used as a clear and precise reference when adopting technology in learning. 


\section{References}

Abuatiq, A., Fike, G., Davis, C., Boren, D., \& Menke, R. (2017). E-learning in nursing: Literature review. International Journal of Nursing Studies, 9(2).

Alias, N., \& Siraj, S. (2012). Effectiveness of Isman Instructional Design Model in Developing Physics Module based on Learning Style and Appropriate Technology. Procedia - Social and Behavioral Sciences, 64, 12-17. https://doi.org/10.1016/j.sbspro.2012.11.002

Bolliger, D. U., Supanakorn, S., \& Boggs, C. (2010). Impact of podcasting on student motivation in the online learning environment. Computers and Education, 55(2), 714 722. https://doi.org/10.1016/j.compedu.2010.03.004

Chaeruman, U. A. (2014). Petunjuk Teknis Bimbingan Praktek Kerja Individu/Kelompok Pelatihan Penulisan Modul Online. Pusat Teknologi Informasi dan Komunikasi Pendidikan Kementrian Pendidikan dan Kebudayaan.

Cojocariu, V.-M., Lazar, I., Nedeff, V., \& Lazar, G. (2014). SWOT Anlysis of E-learning Educational Services from the Perspective of their Beneficiaries. Procedia - Social and Behavioral Sciences, 116, 1999-2003. https://doi.org/10.1016/j.sbspro.2014.01.510

Daniel, S. J. (2020). Education and the COVID-19 pandemic. Prospects, 49(1-2), 91-96. https://doi.org/10.1007/s11125-020-09464-3

Dhawan, S. (2020). Online Learning: A Panacea in the Time of COVID-19 Crisis. Journal of Educational Technology Systems, 49(1), 5-22. https://doi.org/10.1177/0047239520934018

Gagne, R. M. (2010). Educational Research and Development: Past and Future. In Research and Development and School Change (1st ed., p. 9). Routledge. https://www.taylorfrancis.com/chapters/edit/10.4324/9780203781555-7/educationalresearch-development-past-future-robert-gagn\%C3\%A9

Gall, M. D., Gall, J. P., \& Borg, W. R. (2007). Educational Research: An Introduction (8th ed.). Pearson.

Hassanzadeh, A., Kanaani, F., \& Elahi, S. (2012). A model for measuring e-learning systems success in universities. Expert Systems with Applications, 39(12), 10959-10966. https://doi.org/10.1016/j.eswa.2012.03.028

Hayati, S., Setyo Budi, A., \& Handoko, E. (2015, October). Pengembangan Media Pembelajaran Flipbook Fisika untuk Meningkatkan Hasil Belajar Peserta Didik. http://snf-unj.ac.id/kumpulan-prosiding/snf2015/

Hollingsworth, H. L., \& Lim, C. I. (2015). Instruction Via Web-Based Modules in Early Childhood Personnel Preparation: A Mixed-Methods Study of Effectiveness and Learner Perspectives. Early Childhood Education Journal, 43(2), 77-88. https://doi.org/10.1007/s10643-014-0642-9

IAESB. (2016). Guidance to support the implementation of a learning outcomes approach. https://www.ifac.org/publicationsresources/guidance-support-implementation-learn ing-outcomes-approach

Kandri, S. E. (2020, May 12). How COVID-19 is driving a long-overdue revolution in education. https://www.weforum.org/agenda/2020/05/how-covid-19-is-sparking-arevolution-in-higher-education/

Kowitlawakul, Y., Fai Chan, M., Swee Lin Tan, S., Swee Kit Soong, A., \& Wai Chi Chan, S. (2017). Development of an e-Learning Research Module Using Multimedia Instruction Approach. 
Logan, R. M., Johnson, C. E., \& Worsham, J. W. (2021). Development of an E-learning Module to Facilitate Student Learning and Outcomes. Teaching and Learning in Nursing, 16(2), 139-142. https://doi.org/10.1016/j.teln.2020.10.007

McDonald, E. W., Boulton, J. L., \& Davis, J. L. (2018). E-learning and nursing assessment skills and knowledge - An integrative review. In Nurse Education Today (Vol. 66, pp. 166-174). Churchill Livingstone. https://doi.org/10.1016/j.nedt.2018.03.011

Permendikbud 3 Tahun 2020. Retrieved October 11, 2021, from https://jdih.kemdikbud.go.id/arsip/Salinan\%20PERMENDIKBUD\%203\%20TAHUN $\% 202020 \% 20 \mathrm{FIX} \% 20 \mathrm{GAB} . \mathrm{pdf}$

Nirbita, B. N., Joyoatmojo, S., \& Sudiyanto, S. (2018). ICT Media Assisted Problem Based Learning for Critical Thinking Ability. International Journal of Multicultural and Multireligious Understanding, 5(6), 341-348.

Nirbita, B. N., Joyoatmojo, S., \& Sudiyanto, S. (2017). Learning Media based on ICT for Learning Strategy of Accounting Program in Vocational School. 1st International Conference on Vocational Education And Training (ICOVET 2017), 58-61.

Retzlaff, B. J., Phillips, L. A., Fisher, W. W., Hardee, A. M., \& Fuhrman, A. M. (2020). Using e-learning modules to teach ongoing-visual inspection of functional analyses. Journal of Applied Behavior Analysis, 53(4), 2126-2138. https://doi.org/10.1002/jaba.719

Riduwan. (2018). Skala Pengukuran Variabel-Variabel Penelitian. Alfabeta.

Saidah, N. I., \& Nugroho, M. A. (2015). Pengembangan Media Pembelajaran Berbentuk Permainan Edukasi Akuntansi Cari Kata (Acak) Menggunakan Adobe Flash Cs5 Development Permainan Acak As Accounting Education Learning Media. Jurnal Pendidikan Akuntansi Indonesia, XIII(1), 65-74.

Sartika, S. H. (2021). Motivasi Belajar dan Regulasi Diri Mahasiswa Selama Pandemi Covid19. Edunesia: Jurnal Ilmiah Pendidikan, 2(1), 260-271. https://doi.org/10.51276/edu.v2i1.127

Singh, V., \& Thurman, A. (2019). How Many Ways Can We Define Online Learning? A Systematic Literature Review of Definitions of Online Learning (1988-2018). American Journal of Distance Education, 33(4), 289-306. https://doi.org/10.1080/08923647.2019.1663082

Sun, L., Tang, Y., \& Zuo, W. (2020). Coronavirus pushes education online. In Nature Materials (Vol. 19, Issue 6, p. 687). Nature Research. https://doi.org/10.1038/s41563020-0678-8

Ullah, S., Kimani, D., Bai, Y., \& Ahmed, R. (2018). Assessing the design of accounting modules across UK higher educational institutions. Cogent Business and Management, 5(1), 1-12. https://doi.org/10.1080/23311975.2018.1510717

Wulandari, L. (2017). Lintang Wulandari, Sudiyanto, dan Sohidin. Pengembangan Media Pembelajaran Berbasis A dobe Flash untuk Meningkatkan Motivasi Belajar Siswa Pada Pembelajaran Akuntansi di SMK. In Tata Arta" UNS (Vol. 3, Issue 1). 